\title{
Experimental Investigation on Augmenting the Discharge over Ogee Spillways with Nanocement
}

\author{
N. Muthukumaran ${ }^{1}$, G. Prince Arulraj ${ }^{2, *}$ \\ ${ }^{1}$ Department of Civil Engineering, Karunya Institute of Technology and Sciences, India \\ ${ }^{2}$ Karunya Institute of Technology and Sciences, India
}

Received August 3, 2020; Revised September 4, 2020; Accepted September 29, 2020

\begin{abstract}
Cite This Paper in the following Citation Styles
(a): [1] N. Muthukumaran, G. Prince Arulraj, "Experimental Investigation on Augmenting the Discharge over Ogee Spillways with Nanocement," Civil Engineering and Architecture, Vol. 8, No. 5, pp. 838 - 845, 2020. DOI: 10.13189/cea.2020.080511.
\end{abstract}

(b): N. Muthukumaran, G. Prince Arulraj (2020). Experimental Investigation on Augmenting the Discharge over Ogee Spillways with Nanocement. Civil Engineering and Architecture, 8(5), 838 - 845. DOI: 10.13189/cea.2020.080511.

Copyright $\odot 2020$ by authors, all rights reserved. Authors agree that this article remains permanently open access under the terms of the Creative Commons Attribution License 4.0 International License

\begin{abstract}
Due to urbanization, the infiltration has decreased drastically resulting in more runoff. Due to this, dams are receiving more runoff than the design runoff. To avoid over topping of dams due to this excess runoff, the capacity of the spillways has to be augmented. The objective of this research is to determine the effect of nano material on increasing the discharge capacity of Ogee spillways. Ogee spillways were constructed in a rectangular flume. Experiments were carried on a tilting flume of size $10 \mathrm{~m} \mathrm{X} 0.55 \mathrm{~m} \mathrm{X} 0.6 \mathrm{~m}$. The Ogee spillway model was fabricated and plastered with cement mortar 1:3. Three slopes were used and laboratory experiments were performed with varying heads. Another Ogee spillway was made and plastered with cement mortar 1:3 in which $30 \%$ cement was replaced with nano cement. The discharges for the three slopes $(0.003333,0.007778$, and 0.012222$)$ were found for Ogee spillway plastered with cement mortar and also for the Ogee spillway plastered with $30 \%$ of nano cement by varying the heads between $0.5 \mathrm{~cm}$ and $5 \mathrm{~cm}$ above the crest of the spillway in steps of $0.5 \mathrm{~cm}$. It is found that spillway with $30 \%$ nano cement replacement gives more discharge than the spillway plastered with normal cement mortar. Experimental investigations related to porosity, roughness height and SEM analysis also prove that replacement of nanomaterial improves the surface smoothness and hence increasing the carrying capacity of the spillway.
\end{abstract}

Keywords Ogee Spillway, Ordinary Portland Cement, Nanocement, Porosity, Roughness Height, SEM Analysis

\section{Introduction}

Spillway is one of the most important structural components of a dam. Spillways also function as 'diverting agents' for excess amounts of water that is diverted to different canals, thereby the safety of the dams are ensured. The three major components of spillway are (i) Control structure which admits flow to the spillway (ii) Discharge channel which conveys the flow from the control structure to the stream bed below the dam (iii) Terminal structures are energy-dissipating devices that are provided to return the flow to the river without serious scour or erosion at the toe of the dam.

The Ogee spillway is also known as S-shape control weir. Ogee spillway represents the shape of the downstream face of the weir. It is an improved form of a straight drop spillway. The profile of the spillway is made in accordance with the shape of the lower nappe of the free-falling jet. The shape of the lower nappe of the free-falling jet can be determined by the principle of projectile. The jet falls clearly over the face of the spillway and the gap between the jet and the face is kept ventilated. In ogee spillway, the falling water is made to glide over the curved profile of the spillway.

Ogee spillways play a major role in energy dissipation effectively and discharge of flood safely over its downstream end. When water falls from higher head to lower head, it produces high amount of kinetic energy at the foot of the spillway and hence it is necessary to dissipate energy effectively, otherwise it will create scouring, erosion on its chute surface [1]. The Ogee shape 
was first investigated by Bazin H.E. [2], and many authors studied the physical model data from USACE and USBR. [3-5]. In 1950's the US Army corps of Engineers focused on the water discharged over spillways [6]. The Ogee spillway functioning similar to a dam, provides the safe passage of water thereby prevent flooding. In engineering terms, they can be compared in function to safety valves in boilers. Generally, Ogee spillways are utilized as flood release structures on dams [7]. Updating the criteria required for safe hydraulic structures to keep pace with the changes in climate and potentiality hazardous after effects on structural integrity and capacity resulted in the need for continuous expansion and up gradation of spillway capacities to increase the discharge [8].

\section{Materials and Methods}

\subsection{Factors Affecting Spillway Design}

\subsubsection{Safety Considerations Consistent with Economy}

Improperly designed spillway or spillways of inadequate capacity will lead to failure in dams. Properly designed structure of adequate capacity may be found to be only moderately higher in cost than a structure of inadequate capacity.

\subsubsection{Hydrological \& Site Conditions Figures Caption}

The spillway design and its capacity depend on inflow discharge, its frequency, shape of the hydrograph, Dam height, Geological and other site conditions.

\subsubsection{Topographical Features}

The important topographical features which affect spillway design are steepness of terrain, amount of excavation and possibility of its use as embankment material, the possibility of scour, slope stability, safe bearing capacity of soils and permeability of soils [9].

\subsection{Literature Review}

Arun Joji, et.al designed a spillway for a composite dam proposed at Kanthalloor as a part of Pattiserry irrigation project. Pattiserry irrigation project envisages construction of $140 \mathrm{~m}$ long and $23 \mathrm{~m}$ high composite dam, earthen bund with concrete overflow section, across the river chengalar a tributary of Pambar River, located in Kanthalloor village. The project was aimed to irrigate $240 \mathrm{Ha}$ of land in Marayoor area, through $8 \mathrm{~km}$ long unlined canal. Ogee type spillway was suggested for the proposed dam [9].

Dhaktode Asaram, et.al carried out an experimental investigation to determine the effects of different slopes of ogee spillway surface on energy dissipation. Three ogee spillway models were prepared with slope of 1:1, 0.85:1, and $0.75: 1$. Experiments were carried out to investigate the energy dissipation. It was observed that the values of relative energy loss varied between $67 \%$ and $87.17 \%$, $65.03 \%$ and $85 \%$, and $67.20 \%$ and $85.20 \%$, for spillway models with slopes $1: 1,0.85: 1$, and $0.75: 1$, respectively [11].

Mamok suprapto carried out the experiments in the flume setup, Hydro laboratory, Faculty of Engineering of Sebelas Maret University. He used Labyrinth Sharp Crest Spillways (LSCS) to increase the capacity without lowering spillway crest. Six kinds of LSCS have been used in the research. Ogee prototype was made of wood and LSCS was made of acrylic. During the experiment, water was allowed into the flume with varying discharge. At different heads above the spillway, the discharge was measured. Observation has been done both on the Ogee and LSCS. He concluded that the ability of LSCS to discharge water was greater than Ogee spillway. Water flowed through the LSCS, particularly trapezoid type-1, was about $170 \%$ more than that of the Ogee spillways [10].

Harinarayan Tiwari.et.al investigated on the methods to improve the hydraulic competence of spillways. From the study they concluded that, Piano Key Weir (PKW) technology can play a role under the simple fact that it does not inhibit stream flow due to absence of any gate control system. They also concluded that PKW creates water storage in stream itself without involving rehabilitation [16].

Amir kbbas kamanbedast et.al used a physical model to study the surface roughness on ogee spillway. Hydraulic performance graph and the appropriate discharge coefficients were determined. To determine these parameters, they carried out an investigation on a physical hydraulic model. Supreme complex Khuzestan Water and Power Industry performed measurement test. They observed the hydraulic parameters and analyzed discharge coefficient in different field including surface roughness in ogee spillway model. Totally 6 types of surface roughness and 5 different flow rates were considered. As a result, they concluded that relative roughness of spillway increases with decreases in surface roughness and cavitation index [17].

Alpaslan Yarar developed an analytical and Artificial Neural Network (ANN) model to estimate the discharge value passing over Ogee Spillways and the results were compared. A flume having $7.5 \mathrm{~cm}$ width, $15 \mathrm{~cm}$ depth and $5 \mathrm{~m}$ length, was used in the laboratory. Discharge values above the spillway were measured for different heads. Discharge values were also computed by the formula for the measured heads. In this study, it was aimed to investigate the performance of ANN on determining the discharge over the ogee spillways. For this purpose, both experimental and analytical studies were done. It was seen that ANN model produced very accurate results. Overall, the studies presented in this paper showed us that ANN model can be an alternative method to determine the discharge value passing over the spillways [18].

Although the literature may appear exhaustive, no report 
is available on usage of nanomaterial to increase the carrying capacity of existing spillways. In this study nano cement was used along with cement and sand for plastering the exterior surface of the spillway with the objective of increasing the discharge.

\subsection{Properties of Materials}

The normal size of the cement particles ranges between $50 \mu \mathrm{m}$ and $90 \mu \mathrm{m}$. The sizes of nano cement particles range from few nanometers to a maximum of about 100 nanometers. These nano cement particles properties improve the compressive strength of the concrete, lower environmental contamination, provide a thinner final product and have faster setting time and are cost effective. The nanoparticles in the mortar make a smooth surface with less pores and good durability. Nano cement was produced by grinding the Ordinary Portland Cement (OPC) of grade 53. OPC was converted into nano cement by grinding OPC in a Ball mill grinder [12]. The nano cement had size between $90 \mathrm{~nm}$ to $200 \mathrm{~nm}$. In this study M-Sand was used as a fine material for plastering the spillway.

\subsection{Experimental Flume Setup}

A tilting flume of size $10 \mathrm{~m} \times 0.55 \mathrm{~m} \times 0.60 \mathrm{~m}$ was used for carrying out the experiments. The flume consists of an inlet chamber, flume portion and a collecting tank. Water is allowed inside the inlet chamber using three centrifugal pumps of power $5 \mathrm{hp}, 3 \mathrm{hp}$ and $2 \mathrm{hp}$. Water from the inlet chamber was allowed through two vertical layers of weld mesh in order to reduce the turbulence. The flow in the flume can be controlled by two gates, one at the entrance and the other one at the end of the flume. In order to measure the discharge, a collecting tank of size $4.2 \mathrm{~m} \times 0.7 \mathrm{~m} \times 0.6 \mathrm{~m}$ is kept at the end of the flume. A piezometer fixed in the collecting tank was used to find the time required for $15 \mathrm{~cm}$ rise in the collecting tank. The bed slope can be adjusted. In order to visualize the flow, a transparent perspex sheet is fitted in the middle portion of the flume. A hook gauge fitted on a trolley was used to determine the depth of the flow. The fabricated tilting flume is shown in (Figure 1).

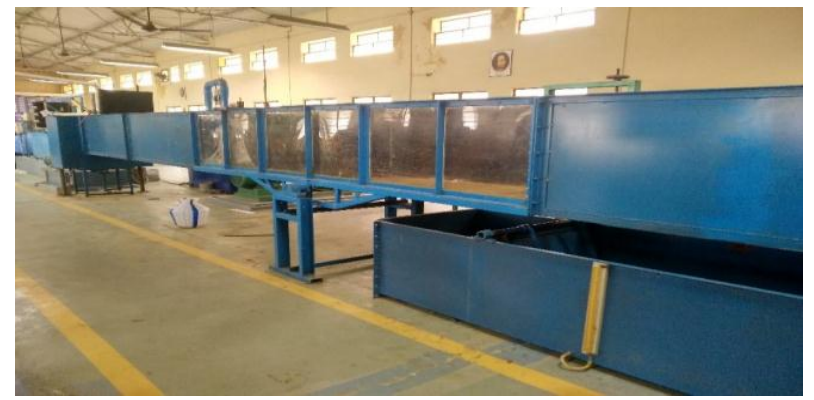

Figure 1. Tilting flume

\subsection{Parameters for the Study}

In this experimental study there are two parameters i) depth over spillway ii) bed slope. The depth considered in this study was varied from $0.5 \mathrm{~cm}$ to $5 \mathrm{~cm}$. Two spillway models were constructed in the rectangular tilting flume. The first spillway model was plastered with CM 1:3. The second one was plastered with CM by replacing $30 \%$ of nano cement.

\subsection{Design of Ogee Spillway}

Ogee spillway is widely used in concrete, masonry and earthen dams. In the earlier periods the Ogee spillways were designed based on Bazin's Profile. To overcome the negative pressure which causes the danger of cavitation and other factors such as hydraulic efficiency, stability and economy, various modified profiles have been proposed.

Several standard ogee shapes have been developed by U.S army corps of engineers at their Waterways Experimental Station (WES). Such shapes are known as 'WES standard spillway shapes'. The d/s profile can be represented by the equation [13].

Where,

$(\mathrm{X}, \mathrm{Y})$ are the coordinates of the points on the Ogee profile with the origin at the highest point of the crest, called the apex. $\mathrm{H}_{\mathrm{d}}$ is the design head including the velocity head. $\mathrm{K}$ and $\mathrm{n}$ are constants depending upon the slope of the upstream face.

In this study, the slope of the upstream side face of the spillway is made vertical, the value of $K$ is taken as 2 and the value of $\mathrm{n}$ is considered and the above equation becomes

$$
\mathrm{x}^{1.85}=19.98 . \mathrm{y}
$$

Coordinates were calculated using the above equation and the profile of the spillway is shown in (Figure 2).

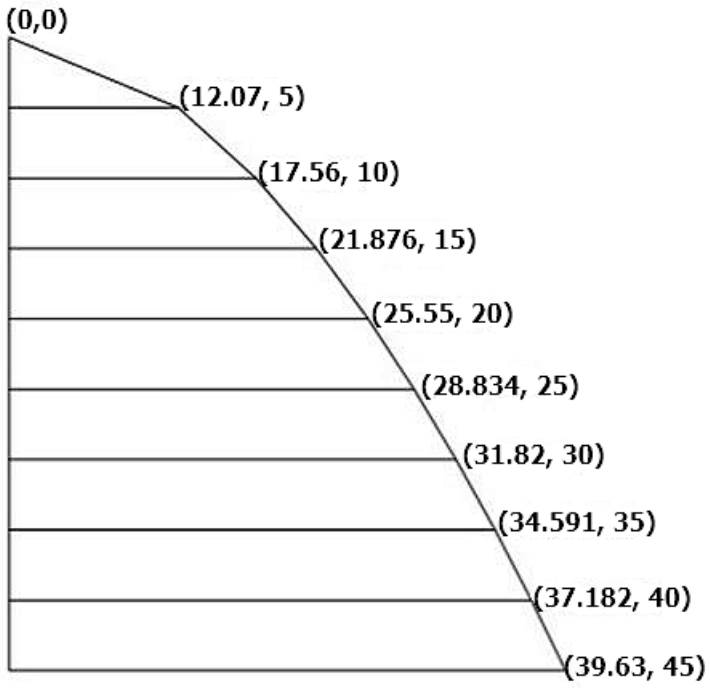

Figure 2. Downstream profile of the proposed spillway model tilting flume 


\subsubsection{Fabrication of Ogee spillway}

The following steps have been followed to fabricate the Ogee spillway. Ogee spillway was constructed inside the tilting flume using bricks in cement mortar 1:3 and cured for seven days.

Two spillways were constructed for conducting the experimental study. Cement Mortar (CM) 1:3 was used to plaster the first spillway. In the second spillway, CM in which the $30 \%$ nano cement was replaced with cement was used to plaster the surface of the spillway. Fabricated Ogee spillway is shown in (Figure 3).

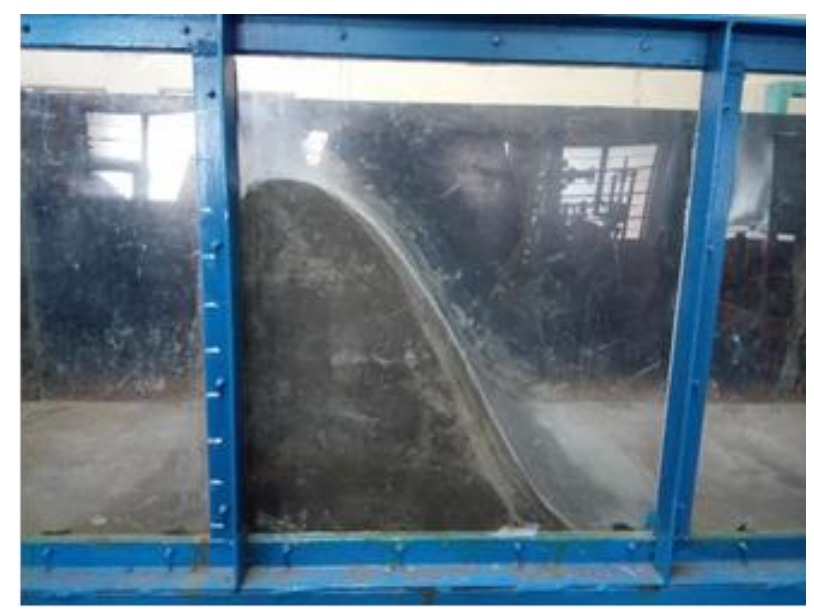

Figure 3. Ogee spillway

\subsubsection{Experimental procedure}

Series of tests were conducted to determine the effect of nano cement in increasing the discharge capacity of the spillway. Three slopes $0.003333,0.007778$ and 0.012222 were used for the study. The slopes used belong to the category of mild slope. Since most of the natural channels and rivers have only mild slope, only mild slope was used for the present study. The head over the spillway and the discharge are given in Table 1.

(Figure 4) shows the stage discharge graph for spillways with and without nano cement when the channels slope was 0.003333 . (Figure 5) shows the stage discharge graph for spillways with and without nano cement when the channel slope was 0.007778. (Figure 6) shows the stage discharge graph for spillways with and without nano cement when the channels slope was 0.012222 .

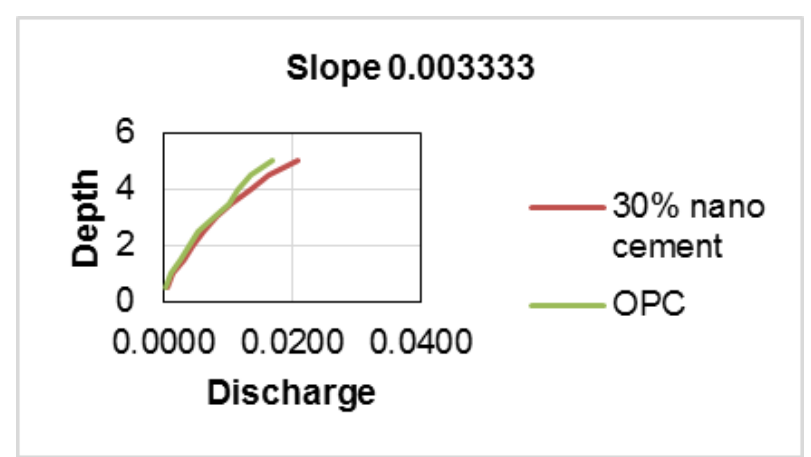

Figure 4. Stage discharge graph for a slope of 0.003333

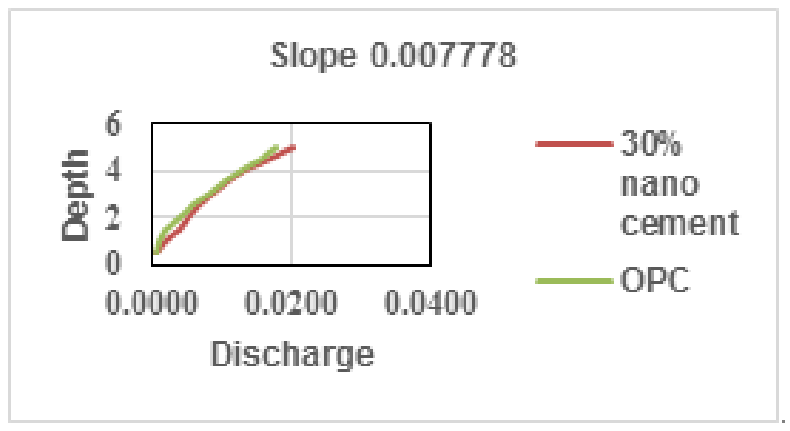

Figure 5. Stage discharge graph for a slope of 0.007778

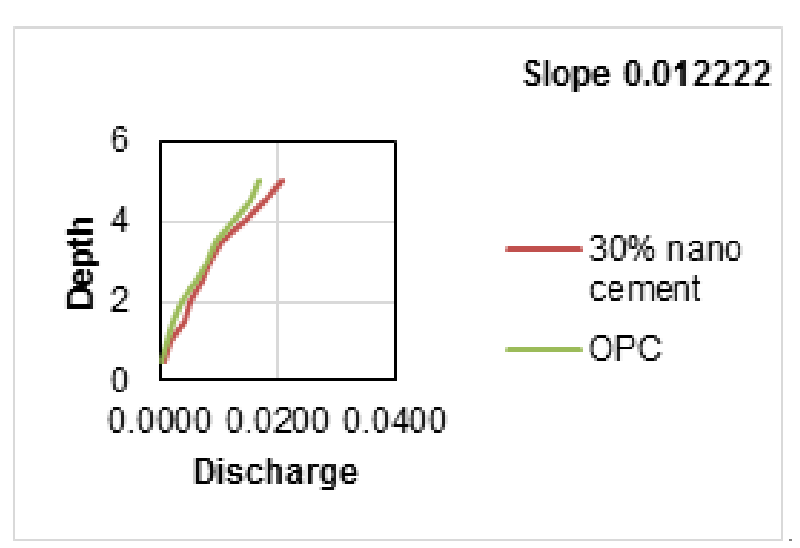

Figure 6. Stage discharge graph for a slope of 0.012222 
Table 1. Discharges over the spillway for various heads

\begin{tabular}{|c|c|c|c|c|c|c|c|}
\hline \multirow{3}{*}{ Sl.No } & \multirow{3}{*}{$\begin{array}{c}\text { Depth } \\
\text { (cm) }\end{array}$} & \multicolumn{6}{|c|}{ Discharge $\left(\mathrm{m}^{3} / \mathrm{s}\right)$} \\
\hline & & \multicolumn{3}{|c|}{ CM 1:3 } & \multicolumn{3}{|c|}{ CM with30 \% nanocement } \\
\hline & & $\begin{array}{c}\text { Slope 1 } \\
(\mathbf{0 . 0 0 3 3 3 3 )} \\
\end{array}$ & $\begin{array}{c}\text { Slope 2 } \\
(\mathbf{0 . 0 0 7 7 7 8 )} \\
\end{array}$ & $\begin{array}{c}\text { Slope 3 } \\
(0.012222) \\
\end{array}$ & $\begin{array}{c}\text { Slope 1 } \\
(\mathbf{0 . 0 0 3 3 3 3 )} \\
\end{array}$ & $\begin{array}{c}\text { Slope 2 } \\
(0.007778) \\
\end{array}$ & $\begin{array}{c}\text { Slope 3 } \\
(\mathbf{0 . 0 1 2 2 2 2}) \\
\end{array}$ \\
\hline 1 & 0.5 & 0.000367 & 0.000452 & 0.000390 & 0.000548 & 0.000630 & 0.000731 \\
\hline 2 & 1 & 0.001019 & 0.001023 & 0.001081 & 0.001565 & 0.001620 & 0.001639 \\
\hline 3 & 1.5 & 0.001826 & 0.001968 & 0.002084 & 0.003140 & 0.003758 & 0.003919 \\
\hline 4 & 2 & 0.003658 & 0.003821 & 0.003953 & 0.004585 & 0.004878 & 0.004930 \\
\hline 5 & 2.5 & 0.005331 & 0.005878 & 0.006113 & 0.006113 & 0.006743 & 0.007164 \\
\hline 6 & 3 & 0.006044 & 0.007688 & 0.007905 & 0.008336 & 0.008651 & 0.009651 \\
\hline 7 & 3.5 & 0.009189 & 0.010189 & 0.009755 & 0.010421 & 0.010917 & 0.012421 \\
\hline 8 & 4 & 0.011463 & 0.012736 & 0.012392 & 0.013485 & 0.013800 & 0.014328 \\
\hline 9 & 4.5 & 0.013485 & 0.015811 & 0.015284 & 0.016375 & 0.016982 & 0.017635 \\
\hline 10 & 5 & 0.016982 & 0.017635 & 0.017982 & 0.020841 & 0.021935 & 0.022841 \\
\hline
\end{tabular}

Table 2. Percentage increase in discharge of spillway with nanocement

\begin{tabular}{|c|c|c|c|c|}
\hline \multirow{2}{*}{ Sl.No } & \multirow{2}{*}{ Depth(cm) } & \multicolumn{3}{|c|}{ \% increase in 30 \% of Nano cement } \\
\cline { 2 - 5 } & & $\begin{array}{c}\text { Slope 2 } \\
(\mathbf{0 . 0 0 7 7 7 8})\end{array}$ & $\begin{array}{c}\text { Slope 2 } \\
(\mathbf{0 . 0 0 7 7 7 8})\end{array}$ & $\begin{array}{c}\text { Slope 2 } \\
(\mathbf{0 . 0 0 7 7 7 8})\end{array}$ \\
\hline 1 & 0.5 & 49.22 & 39.29 & 57.56 \\
\hline 2 & 1 & 53.58 & 58.30 & 51.53 \\
\hline 3 & 1.5 & 71.99 & 90.98 & 28.03 \\
\hline 4 & 2 & 25.36 & 27.66 & 17.19 \\
\hline 5 & 2.5 & 14.67 & 14.71 & 22.08 \\
\hline 6 & 3 & 37.93 & 12.53 & 27.32 \\
\hline 7 & 3.5 & 13.40 & 7.14 & 15.63 \\
\hline 8 & 4 & 17.65 & 8.35 & 15.38 \\
\hline 9 & 4.5 & 21.43 & 7.41 & 27.02 \\
\hline
\end{tabular}

The percentage increase in the discharge values for the spillways with nano material are given in Table 2.

From (Figure 4), (Figure 5), (Figure 6) and Table 2, it was observed that the discharge over the spillway increases for the spillways with nano cement. The percentage increase varies between 13.40 and 71.99 for the spillway with $30 \%$ nano cement for the slope 0.003333 . The percentage increase varies between 7.14 and 90.98 for the spillway with $30 \%$ nano cement for the slope 0.007778 . The percentage increase of discharge varies with 15.38 to 88.03 for spillway with $30 \%$ nano cement for the slope 0.012222 .

The discharges over the spillway with normal cement mortar and spillway with $30 \%$ nano cement were compared. It is observed that the discharge over spillway with $30 \%$ nano cement is more. The reasons for the increase in the discharge are smoother surface and reduced porosity of the surface when nano cement was used.

\subsection{Analysis of the Results}

\subsubsection{SEM Analysis}

The Nano cement particles were prepared by ball grinding the cement particles. Properties of nano cement include the high compressive strength, increase in smoothness and reduction in the roughness of the surface. The reduction in the roughness increases the flow rate. These Nanoparticles also fill the pores of the mortar and hence a smoother surface is obtained.

The SEM images of normal cement mortar (CM 1:3) and cement mortar with $30 \%$ of nanocement are given in (Figure 7) and (Figure 8) respectively. 


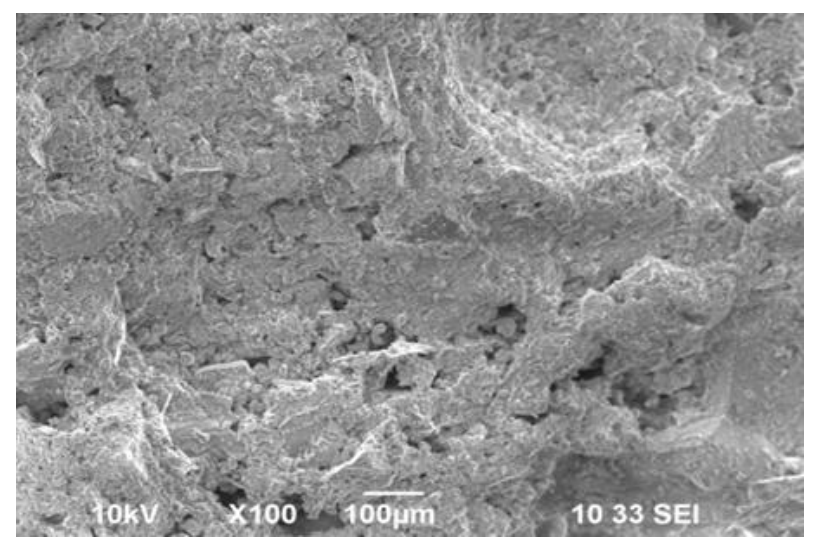

Figure 7. SEM images of normal cement mortar (CM 1:3)

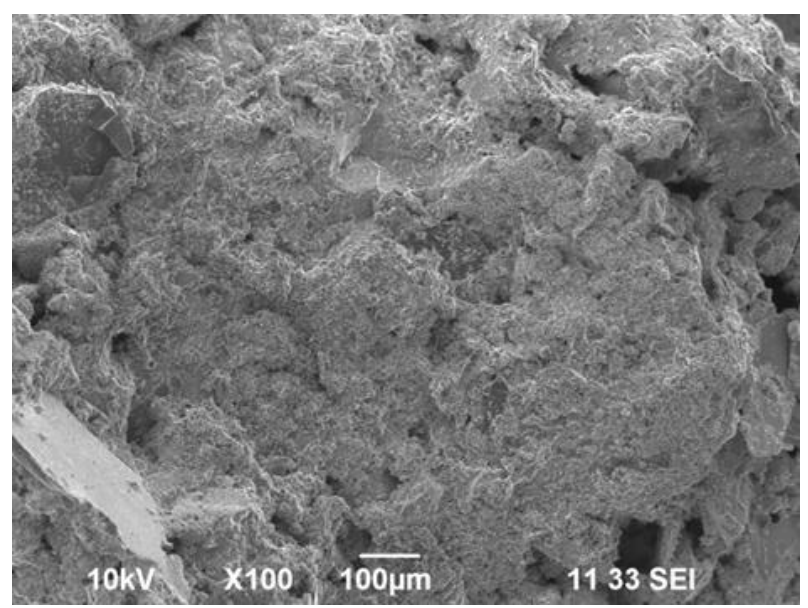

Figure 8. SEM images of cement mortar with $30 \%$ of nanocement

From the SEM images, it can be seen that the nano sized particles present in the mortar make the surface smooth and hence the discharge increases.

\subsubsection{Surface roughness}

Surface roughness often called as roughness, is a component of surface texture. It is quantified by the deviations in the normal vector of a real surface from its ideal form [14, 15]. If these deviations are large, the surface becomes rough; if they are small, the surface is smooth. Rough surfaces usually wear out more quickly and have higher friction coefficient than smooth surfaces.

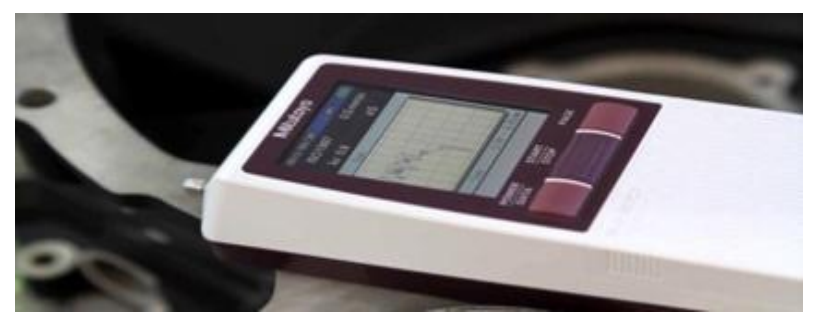

Figure 9. Surface roughness tester

The portable surface roughness tester Mitutoyo SJ-210 model (Figure 9) was used to determine the surface roughness parameters $R_{a}, R_{q}$ and $R_{z}$. The 2.4-inch color graphic back-lit LCD provides excellent readability and an intuitive display. Up to 10 measurement conditions and one measured profile can be stored in the internal memory. An optional memory card can be used as an extended memory to store large quantities of measured surface profiles and setup conditions. The instrument shows the measured values in micrometers.

\subsubsection{Surface Roughness Parameters}

A roughness value can either be calculated on a profile (line) or on a surface (area). The profile roughness parameter $R_{a}$ (Arithmetic mean roughness parameter), $R_{z}$ (Average depth of roughness parameter), $\mathrm{R}_{\mathrm{q}}$ (Root mean square roughness) are used during the study.

Profile roughness parameters are shown in (Figure 10).
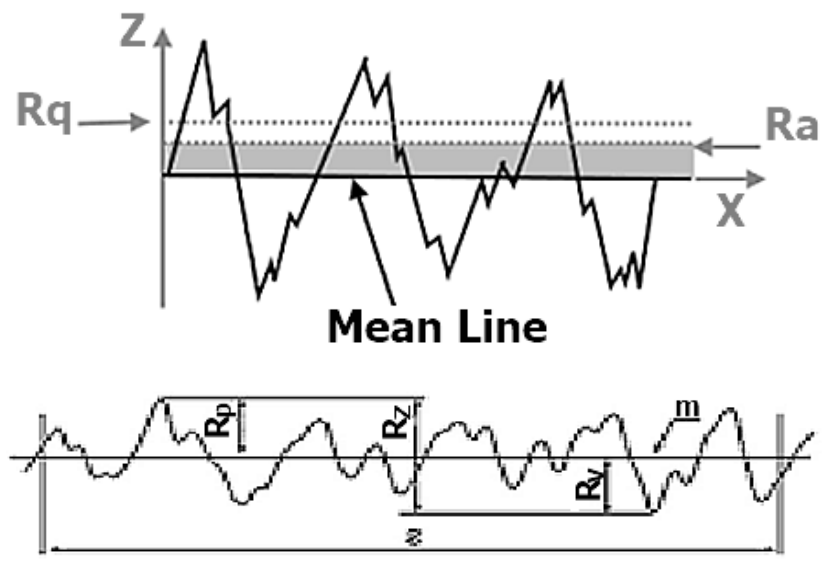

Figure 10. Surface profile roughness parameters

The various roughness heights of normal cement mortar plastering and for the plastering with $30 \%$ nano cement are given in Table 3 .

Table 3. Surface roughness of normal cement and cement mortar with $30 \%$ nano cement

\begin{tabular}{|c|c|c|}
\hline $\begin{array}{c}\text { Roughness } \\
\text { height }\end{array}$ & $\begin{array}{c}\text { Cement } \\
\text { mortar 1:3 }\end{array}$ & $\begin{array}{c}\text { Cement mortar with 30 \% } \\
\text { nano cement }\end{array}$ \\
\hline $\mathrm{R}_{\mathrm{a}}$ & $5.444 \mu \mathrm{m}$ & $4.884 \mu \mathrm{m}$ \\
\hline $\mathrm{R}_{\mathrm{q}}$ & $6.818 \mu \mathrm{m}$ & $5.958 \mu \mathrm{m}$ \\
\hline $\mathrm{R}_{\mathrm{z}}$ & $32.195 \mu \mathrm{m}$ & $24.056 \mu \mathrm{m}$ \\
\hline
\end{tabular}

It is observed from the tables that the roughness height of cement mortar tiles with nano cement $30 \%$ is less than that of normal cement mortar tiles. The decrease in roughness height indicates that nano cement makes the exterior surface of the spillway smoother. $\left(\mathrm{R}_{\mathrm{a}}\right.$ being 4.884 $\mu \mathrm{m}$ for spillway with nano cement whereas the value of $R_{a}$ is $5.442 \mu \mathrm{m}$ for spillway without nano cement.

The reduction in the average roughness height is $11.53 \%$.

\subsubsection{Porosity}

The porosity value of normal cement mortar is presented in Table 4. 
Table 4. Porosity of normal cement mortar tiles

\begin{tabular}{|c|c|c|c|c|}
\hline \multirow{2}{*}{ Sl.no } & \multicolumn{2}{|c|}{$\begin{array}{c}\text { Weight of normal } \\
\text { cement mortar tiles }\end{array}$} & \multirow{2}{*}{ Porosity } & $\begin{array}{c}\text { Average } \\
\text { value of } \\
\text { porosity } \\
\text { (\%) }\end{array}$ \\
\cline { 2 - 4 } & $\begin{array}{c}\text { Initial } \\
\text { weight } \\
\text { (kg) }\end{array}$ & $\begin{array}{c}\text { Final } \\
\text { weight } \\
(\mathbf{k g})\end{array}$ & \multirow{2}{*}{6} \\
\hline 1 & 8.95 & 9.55 & 6.70 & \multirow{2}{*}{6.770} \\
\hline 2 & 8.31 & 8.88 & 6.86 & \\
\hline 3 & 7.85 & 8.38 & 6.75 & \\
\hline
\end{tabular}

The average value of porosity for the normal cement mortar surface is found to be $6.770 \%$.

The porosity values of cement mortar with $30 \%$ nano cement is presented in Table 5.

Table 5. Porosity of normal cement mortar with $30 \%$ nanocement

\begin{tabular}{|c|c|c|c|c|}
\hline \multirow[t]{2}{*}{ Sl.no } & \multicolumn{2}{|c|}{$\begin{array}{l}\text { Weight of cement } \\
\text { mortar tiles with } \\
\text { nano-cement } 30 \%\end{array}$} & \multirow{2}{*}{$\begin{array}{c}\text { Porosity } \\
(\%)\end{array}$} & \multirow{2}{*}{$\begin{array}{c}\text { Average } \\
\text { value of } \\
\text { porosity } \\
(\%)\end{array}$} \\
\hline & $\begin{array}{c}\text { Initial } \\
\text { weight }(\mathrm{kg})\end{array}$ & $\begin{array}{c}\text { Final } \\
\text { weight }(\mathrm{kg})\end{array}$ & & \\
\hline 1 & 8.44 & 8.72 & 3.32 & \multirow{3}{*}{3.500} \\
\hline 2 & 8.57 & 8.88 & 3.62 & \\
\hline 3 & 9.02 & 9.34 & 3.55 & \\
\hline
\end{tabular}

The average value of porosity for the cement mortar with $30 \%$ nanocement is found to be $3.500 \%$.

It is observed that the average value of porosity for the cement mortar with $30 \%$ nanocement is $48.30 \%$ less than that of normal cement mortar.

The decrease in porosity is found to be $48.30 \%$. This indicates that nano cement makes the exterior surface of the spillway smoother and hence porosity and friction are reduced facilitating a higher discharge.

\section{Conclusions}

The following conclusions were derived based on this research.

Nano material makes the exterior surface of the spillway smoother and hence porosity and friction are reduced.

The increase in discharge of spillway with $30 \%$ Nano cement is found to vary from $7.14 \%$ to $90.98 \%$.

From the SEM images, it can be seen that the nanosized particles present in the mortar make the surface smooth and hence the discharge increases.

It is found that the roughness height of cement mortar with $30 \%$ nano cement is less than that of normal cement mortar tiles. The decrease in roughness height indicates that nano cement makes the exterior surface of the spill way smoother.

It is observed that the average value of porosity for the cement mortar with $30 \%$ nano cement is less than that of normal cement mortar.

The decrease in porosity is found to be $48.30 \%$. This indicates that nano cement makes the exterior surface of the spillway smoother and hence the discharge over spillway increases.

\section{Acknowledgements}

The authors acknowledge research facility provided by the Department of Civil Engineering, Karunya Institute of Technology and Sciences, Coimbatore, Tamil Nadu, India for carrying out the research presented in this research paper.

\section{REFERENCES}

[1] Ashiq, M., Sattar. Optimization of Energy Dissipation works for Nai-Gaj Dam spillway, American Society of Civil Engineers (ASCE), 2010.

[2] Bazin, H. E.1888; Recent experiments on the flow of water over weirs, Proceedingl, EngiMel'8' Club of Philadelph.ia, 16 (6): 393-148. Ba.zin's data were reprinted almost eutirely by G. W. Rafter in Report on special water-Supply investigation, Congressional Documents 4146 and 4147, Washington, D.C., pp. 571-950, 1990; and Hydrology of the State of New York, 'l'few York State musuem Bulletin 85, Albany, N.Y.,1905.W. Zabierowski, A. Napieralski. Chords classification in tonal music, Journal of Environment Studies, Vol.10, No.5, 50-53.

[3] Chow, V. T. Open-channel hydraulics, McGraw-Hill, New York, 365-380, 1986.

[4] Murphy, T. E. Spillway crest design. MP H-73-5, U.S. Army Engineer Waterways Experiment Station, Vicksburg, Miss., 1973.

[5] Design of small dams, U.S. Bureau of Reclamation, U.S. Government Printing Office, Washington, D.C., 1977.

[6] Maynord, S. T. General spillway investigation. Tech. Rep. HL-85-1, U.S. Army Engineer Waterways Experiment Station, Vicksburg, 1958

[7] US Army Corps of Engineers Waterways Experiment Station., revised in subsequent years, Corps of Engineers Hydraulic Design Criteria, 1952.

[8] Xlyang, J., Cederström, M. Modification of spillways for higher discharge capacity. J. Hydraul. Res. 45 (5), 701-709. 2007.

[9] Arun Joji, Nithya Thomas, Reshma Jose, Yapung Chije, Solly George. Spillway design for a Composite dam, International Journal of Engineering and Technology (IRJET) e-ISSN 2395-0056 Volume: 03, Issue: 04, 2557-2564, 2016.

[10] Mamok suprapto Increase spillway capacity using labyrinth weir, Journal of procedia engineering, volume 54, 440-446, 2013.

[11] Dhaktode Asaram, Gatne Deepankar, Gurjeet Singh, Kasabe Vishal, Kasawa Akshay. Energy dissipation by using different slopes of Ogee spillway, International Journal of 
Engineering and General Science, Volume 4, Issue 3, May June, ISSN 2091-2730,18-22, 2016.

[12] Alaa A. Abdul-hamed, Furhad M. Othman, Noor A. Hmeed. The effects of nano flyash on properties of cement mortar, International Journal of Advanced Engineering Technology, Vol. 9, 1-8, 2018.

[13] Santosh Kumar Garg, Irrigation Engineering and Hydraulics Structures, Khanna Publishers, Revised edition 2010.

[14] ISO4287: Geometrical product specifications (GPS) surface texture, profile method- Terms, definitions and surface texture parameter (ISO 4287:1997.

[15] Clausen R, Stemgenberg J. Roughness of shot-peened surfaces - definitions and measurement, the 7 th
International conference on shot peening, Institute of precision mechanics, Warsaw, Poland, 69-77.

[16] Harinarayan Tiwari. Nayan Sharma. Development to improve hydraulic competence of spillways, Journal of aquatic procedia, Volume:4, 841-846, 2015.

[17] Amir Abbas Kamanbedast, Mostafa Bahmani, Roozbeh Aghamajidi. The effect of surface roughness on discharge coefficient and cavitation of ogee spillways using physical model. Journal of applied science and agriculture, Volume: 6,2442-2448, 2014.

[18] Alpaslan Yarar. Analytical and artificial neural network models of discharge value passing over ogee spillway. Journal of Engineering, Science and Technology, Volume: 5, 370-376, 2017. 